\title{
Mango Seed Kernel Agronomical Bio-Waste for Ecofriendly Cotton Dyeing: Optimization of Dyeing Period and Temperature
}

\author{
Manindra Nath Roy ${ }^{1,2}$, M. Tauhidul Islam ${ }^{1,3, *}$, Md. Saddam Hossain Khan ${ }^{1}$, Kallol Sarker ${ }^{1}$, \\ Md. Abdullah Al Mamun'

\begin{abstract}
${ }^{1}$ Department of Textile Engineering, Mawlana Bhashani Science and Technology University, Tangail-1902, Bangladesh ${ }^{2}$ Department of Textile Engineering, University of South Asia, Dhaka-1213, Bangladesh ${ }^{3}$ Department of Material Science and Engineering, National Cheng Kung University, Tainan-701, Taiwan
\end{abstract}

\begin{abstract}
Typical synthetic colorant and their application processes include various negative eco-toxicological effect and human health risk. Intend to depose the impediments of synthetic dyeing herein mango seed kernel agronomical bio-waste was employed for sustainable dyeing of cotton fabric. $100 \%$ cotton knitted single jersey commercially scoured-bleached fabric having areal density of 160 grams per square meter was used for this study. Natural dye was extracted by alkali extraction method from raw seed kernel of Mangifera indica. Optimum dyeing temperature and duration were quantified Colorimetric appearance of the dyed samples for different dyeing condition were evaluate by using CIE $\mathrm{L}^{*} \mathrm{a} * \mathrm{~b} *$ color space in terms of color co-ordinates, color strength $(\mathrm{K} / \mathrm{S})$, brightness index (BI) and degree of color levelness values. Dye fiber bonding stability of the dyed fabric was evaluated in terms of colorfastness to wash, water, perspiration, rubbing and light. Overall the colorfastness values were recorded as 4-5 except light fastness. Excellent colorimetric appearance and serviceability indicates future green coloration of cotton fabric through mango seed kernel as well as decent agronomical bio-waste management.
\end{abstract}

Keywords Environment and Health, Green Coloration, Natural Dye, Mango Seed Kernel (MSK), Bio-Waste, Serviceability

\section{Introduction}

In recent decades, synthetic coloration of textiles is the alarming issue around the world because of ecological imbalance as well as a future threat for human being. It was noticed that approximately $250-350 \mathrm{~kg}$ water consumed to process per $\mathrm{kg}$ cotton fabric. Additionally unexhausted synthetic dyes and hazard chemicals produces about $4-37 \%$ waste water with huge amount of pollutants $[01,02]$ more enough for environmental threat. Also exhausted and unexhausted synthetic dyes in fabric caused various human health toxicity as skin sensitization, respiratory problem, carcinogenesis, headaches, dark circle under the eyes, fatigue, lack of concentration etc. [03, 04, 05]. In special cases it may leads cancer [06].

To release from this problem, eco-friendly natural dyeing technologies are thriving worldwide as alternative of synthetic colorant. Inherently the natural dyes have variety of shades and tones. Besides, they are safe for human body and environment, abundant in availability, cheap, and have no disposal problems [07].

Plants, animals or insects, minerals are the typical sources of natural dyes. Now-a-days, different renewable bio-resources products were also using as sources of natural dye to gratify the ecological balance [08].

Among several plant sources, mango could an excellent option of dye source. In a complete mango fruit, the seed partake about 10 to $25 \%$. And in a seed the kernel share is ranging between $45-75 \%$. And roughly the seed presumes as $20 \%$ share of the whole fruit [09]. Moreover, mango is considered as the "King of Fruits" in Indian subcontinent and also popular in many tropical courtiers due to its unique delicious taste, captivating flavor with multifarious color, source of nutritive values. Moreover, mango possess different functional properties namely anti-oxidant, anti-viral, anti-diabetic, anti HIV, anti-bacterial, anti-fungal, anti-allergic, anti-microbial, pyro-lytic liquid $[10,11]$. So, these vast deployments of mango yields huge amount of agronomical waste which have no remarkable effective exploitation. Regarding mango byproduct utilization, several researchers had used mango waste for decolonization of textile effluent. [12, 13, 14, 15].

But mango seed kernel possesses tannins and mangiferin which may have outstanding dyeing characteristics $[11,16]$. To our best concern so far no study had been carried out for cotton coloration with mango seed kernel. So for the first time here mango seed kernel extracted dye was used for cotton coloration. 
In this study, dye was extracted from mango seed kernel according to alkali extraction method. Dying temperature and time was optimized in terms of several colorimetric properties and dye-fiber binding permanency and agronomical bio-waste of mango was effectively exploited as well.

\section{Experimental}

\subsection{Materials}

Fabric used in this experiment includes commercially scoured-bleached $100 \%$ cotton knitted single jersey structure having areal density of 160 grams per square meter having geometrical properties: course per inch (CPI) $=52$, Wales per inch $(\mathrm{WPI})=35$, stitch length $=2.70 \mathrm{~mm}$ and yarn count $28 \mathrm{Ne}$. Fabric was collected from Sparkel Knit Composite Limited, Savar, Dhaka, Bangladesh. The color co-ordinates value of the investigated scoured bleached sample depicts by the following table 1 .

Table1. Whiteness Index (WI), Brightness Index (BI) and Color co-ordinate value of commercially scoured-bleached cotton fabric

\begin{tabular}{|c|c|c|c|c|c|c|}
\hline WI & BI & $\mathrm{L}^{*}$ & $\mathrm{a}^{*}$ & $\mathrm{~b}^{*}$ & $\mathrm{c}^{*}$ & $\mathrm{H}$ \\
\hline 65.89 & 89.68 & 94.15 & -0.38 & 3.45 & 3.72 & 92.82 \\
\hline
\end{tabular}

\subsubsection{Dyes and Chemical:}

Mango (Mangifera indica) seed kernel agronomical waste used as a dye source for this investigation which was collected from Mawlana Bhashani Science and Technology University, Santosh, Tangail-1902. Caustic soda $(\mathrm{NaOH})$ and water (laboratory grade) used for dye extraction. ISO Standard Soap, James heal, England had used for removing the unfixed dye from the surface of colored sample.

\subsection{Methods}

\subsubsection{Dye Extraction:}

At first the ripen mango (Mangifera Indica) seed raw kernel agronomical waste were separated by sharp knife and then crash it in a Hamam dasta. Around 40-50g mango raw kernel weighted in an electric balance and $2 \mathrm{~g}$ of Caustic soda dissolved in $200 \mathrm{ml}$ water. Then boiled it at $100^{\circ} \mathrm{C}$ about 60 minutes and cooled. A brownish jelly type phase was achieved. The mango kernel jelly strained through the nylon strainer carefully. The extracted dye liquor prepared for dyeing and stored in a glass container in cool place to protect the extracted dye solution from sun rays and avoid unwanted evaporation and possible chemical reaction [17].

\subsubsection{Dyeing}

Dyeing had carried out according to exhaust method by Infra-red lab sample dyeing machine (XIAMEN RAPID, China) at $40,60,80,100$ and $110^{\circ} \mathrm{C}$ respectively for 60 minutes (Figure 2) to find out the optimum dyeing temperature. In all cases $100^{\circ} \mathrm{C}$ was noticed as the best dyeing temperature. Latter the samples were dyed about $110,110,90,80,70,60$, and 50 minutes to find out the best dyeing time (Figure2). After dyeing action, the bath was cooled at $40^{\circ} \mathrm{C}$ and samples were washed at room temperature. Samples were squeezed and air dried in flat dryer machine (MESDAN, Italy).Then soaping was performed for removing unfixed dye form the fabric surface by $0.5 \mathrm{~g} / \mathrm{L}$ ISO standard soap at $80{ }^{\circ} \mathrm{C}$ for 10 minutes. For both dyeing and soaping material to liquor ratio had kept as 1:20 [18].

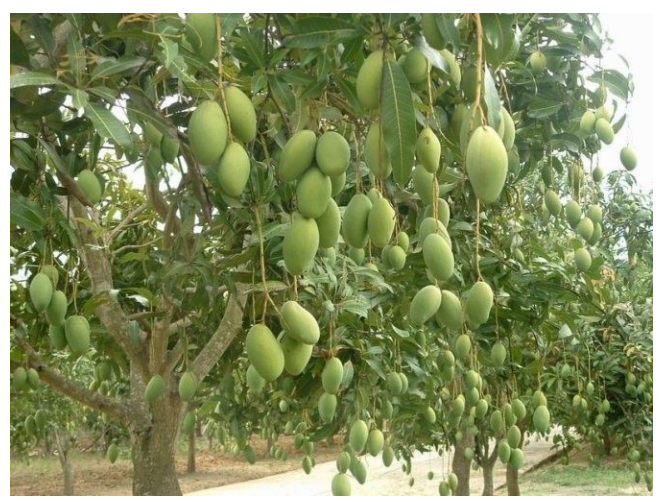

Mango tree with fruits

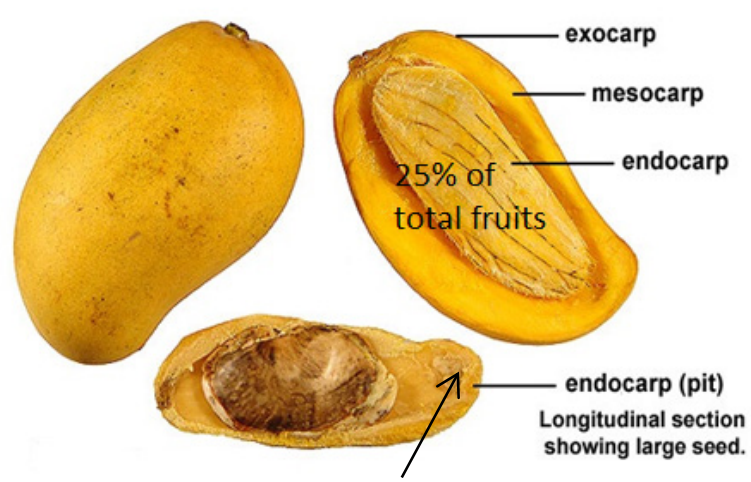

Mango seed kernel (45-70\% of seed)

Figure 01. Different parts of Mango 


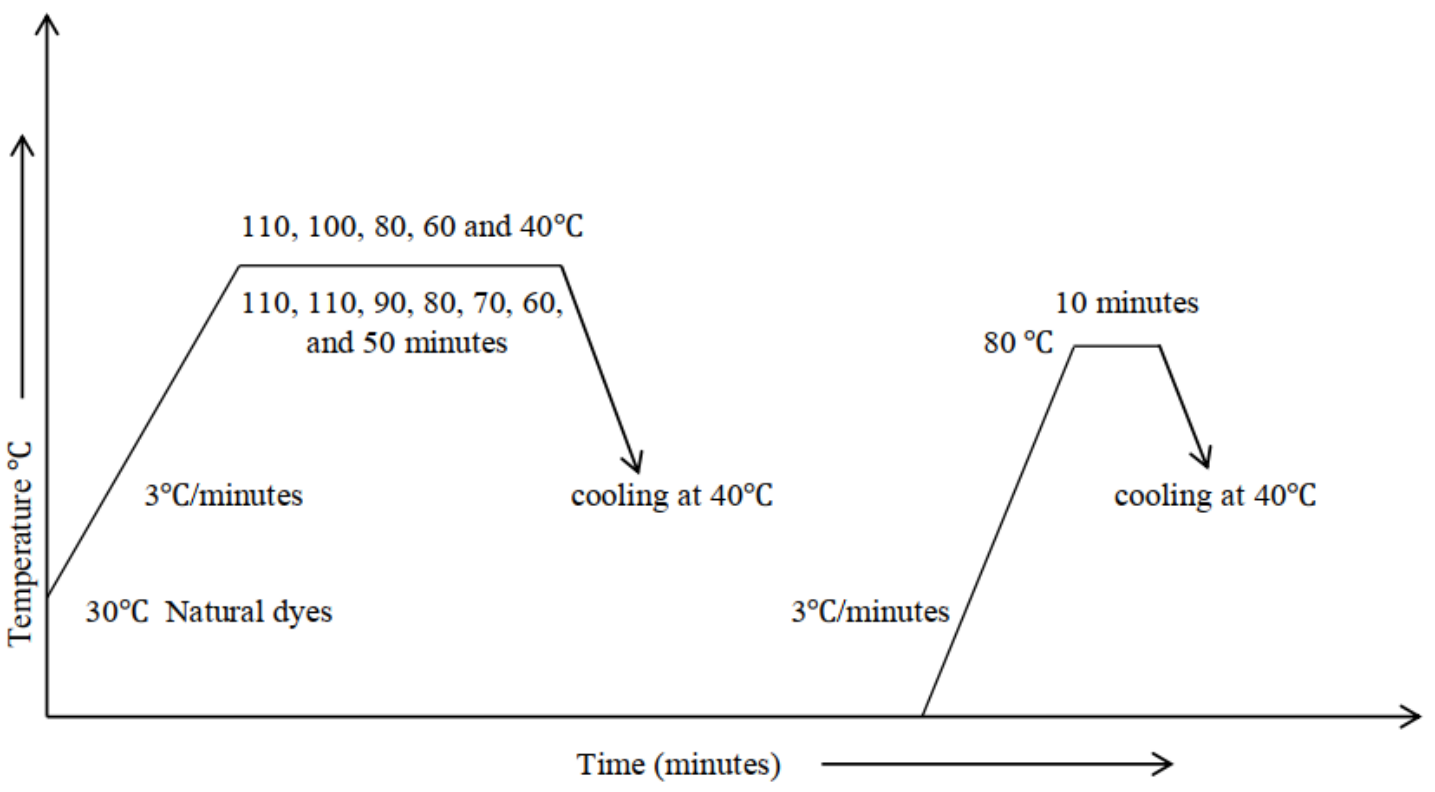

Figure 02. Dyeing Curve

\subsubsection{Determination of Color Coordinates Value:}

Dual beam reflectance Data-color spectrophotometer, (Spectroflash SF 650X, USA) was used to determine the color co-ordinates value of dyed sample based on CIE Lab system. Following setting was used: Illuminant D65, Medium area view, Specular included and CIE 1964 supple-mental standard observer (10 ${ }^{\circ}$ observer). Each sample was folded twice to give an opaque view with four plies and the color coordinates values were measured automatically [19].

\subsubsection{Determination of Degree of Color Levelness:}

The degree of color levelness of each dyed sample was measured by using Data color spectrophotometer considering the reading-1 as standard and other nines as sample batches. Data for each batch are analyzed with respect to color difference, $\Delta \mathrm{E}$ value. $\Delta \mathrm{E}$ is a single value that takes into account the differences between the $\mathrm{L}^{*}, \mathrm{a}^{*}$ and $b^{*}$ values of the sample and standard in the CIE $\mathrm{L} * \mathrm{a} * \mathrm{~b} *$ color system. The Equation 1 was used to calculate the $\Delta \mathrm{E}$ value [20]

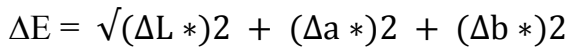

Where, $\Delta \mathrm{L}^{*}=\mathrm{L}^{*}$ sample $-\mathrm{L}^{*}$ standard, $\Delta \mathrm{a}^{*}=\mathrm{a}^{*}$ sample $-\mathrm{a}^{*}$ standard, $\Delta \mathrm{b}^{*}=\mathrm{b}^{*}$ sample $-\mathrm{b}^{*}$ standard; standard refers to the reading-1 in dyed fabric, sample refers to other readings in the corresponding dyed fabric. The degree of levelness was described according to $\Delta \mathrm{E}$ values [21] as shown in Table 2.

\subsubsection{Determination of Color Strength}

The color strength $(\mathrm{K} / \mathrm{S})$ value of the dyed samples was evaluated by data color spectrophotometer based on
Kubelka Munk theory which gives the relationship (Equation 2) between $\mathrm{K} / \mathrm{S}$ and $\mathrm{R}$ as mentioned below $[22,23]$

$$
\frac{\mathbf{K}}{\mathrm{S}}=\frac{(\mathbf{1}-\mathbf{R})^{2}}{2 \mathrm{R}}
$$

Where, $\mathrm{R}$ is reflectance of an incident light from the dyed material, $\mathrm{K} \& \mathrm{~S}$ is absorption and scattering coefficient of the dyed fabric respectively.

Table 2. Suggested interpretation of $\Delta \mathrm{E}$ values

\begin{tabular}{|c|c|c|}
\hline$\Delta$ E values & $\begin{array}{c}\text { Visual appearance of } \\
\text { levelness }\end{array}$ & Extent of unlevelness \\
\hline$\leq 0.20$ & Excellent levelness & Unlevelness not detectable \\
\hline $0.21-0.50$ & Good levelness & $\begin{array}{c}\text { Unlevelness noticeable under } \\
\text { close examination }\end{array}$ \\
\hline $0.51-1.0$ & Poor levelness & Apparent unlevelness \\
\hline$>1.0$ & Bad levelness & Conspicuous unlevelness \\
\hline
\end{tabular}

\subsubsection{Determination of Brightness Index:}

Brightness index of dyed sample was measured according to (ISO-2470-1977) [18] method using following relationship (Equation 3) after measuring the reflectance value of the corresponding sample by Data color spectrophotometer according to specified setting only specular excluded was set. Each sample was folded twice to give an opaque view with four plies and the reflectance value was measured automatically.

Brightness Index $=$

Refletance value of the substrate at $360 \mathrm{~nm}$ Reflectance value of white diffuser or white tile at $360 \mathrm{~nm}$

\subsubsection{Determination of Color Fastness}

Colorfastness properties of selected dyed samples were evaluated by following international standard method. Color fastness to wash, rubbing (dry and wet), light, water, 
perspiration, was accessed by using grey scale (rating $1-5$, where 1 - poor, 2 - fair, 3 - good, 4 - very good and 5 excellent and for light fastness blue wool rating $1-8$, where 1 - poor, 2 - fair, 3 -moderate, 4 - good, 5 - better, 6 - very good, 7 - best and 8 -excellent) of color change and staining according to ISO 105-C06:2010 [24], ISO-105x12:1995 [25], EN ISO 105-E01:2013 [26], ISO 105-E04:2013 [27] and EN ISO 105-B02: 2013 [28] correspondingly.

\section{Result and Discussion}

\subsection{Color Co-ordinates value of dyed samples}

Table 3 indicates the CIELAB color co-ordinates of dyed samples

Table 3. Color co-ordinate value

\begin{tabular}{|c|c|c|c|c|c|c|}
\hline \multicolumn{2}{|c|}{ Sample Types } & \multicolumn{5}{|c|}{ Color co-ordinates } \\
\hline $\begin{array}{l}\text { Temp } \\
\left({ }^{\circ} \mathrm{C}\right)\end{array}$ & $\begin{array}{c}\text { Time } \\
\text { (minutes) }\end{array}$ & $\mathrm{L}^{*}$ & $a^{*}$ & $b^{*}$ & $\mathrm{c}^{*}$ & $\mathrm{~h}^{\circ}$ \\
\hline $110^{\circ} \mathrm{C}$ & \multirow{5}{*}{$60 \mathrm{~min}$} & 62.66 & 6.53 & 12.32 & 13.62 & 63.05 \\
\hline $100^{\circ} \mathrm{C}$ & & 60.53 & 6.07 & 11.72 & 13.20 & 62.63 \\
\hline $80^{\circ} \mathrm{C}$ & & 60.89 & 6.93 & 12.56 & 14.31 & 62.72 \\
\hline $60^{\circ} \mathrm{C}$ & & 61.79 & 6.65 & 13.23 & 14.81 & 63.33 \\
\hline $40^{\circ} \mathrm{C}$ & & 59.56 & 6.41 & 12.58 & 14.12 & 63.01 \\
\hline \multirow{7}{*}{$100^{\circ} \mathrm{C}$} & $110 \mathrm{~min}$ & 63.99 & 6.33 & 13.16 & 14.61 & 64.31 \\
\hline & $100 \mathrm{~min}$ & 60.42 & 7.39 & 14.44 & 16.22 & 62.90 \\
\hline & $90 \mathrm{~min}$ & 61.23 & 6.68 & 12.87 & 14.5 & 62.56 \\
\hline & $80 \mathrm{~min}$ & 62.51 & 7.08 & 13.95 & 15.64 & 63.07 \\
\hline & $70 \mathrm{~min}$ & 62.56 & 5.6 & 10.74 & 12.21 & 62.45 \\
\hline & $60 \mathrm{~min}$ & 62.32 & 6.26 & 11.46 & 13.95 & 63.31 \\
\hline & $50 \mathrm{~min}$ & 61.76 & 6.19 & 12.21 & 13.69 & 63.1 \\
\hline
\end{tabular}

At 60 minutes, with varying temperatures the lightness $\left(\mathrm{L}^{*}\right)$ the samples order were found as $62.66>61.79>60.89>60.53>59.56$ respectively for $110^{\circ} \mathrm{C}>60^{\circ} \mathrm{C}>80^{\circ} \mathrm{C}>100^{\circ} \mathrm{C}>40^{\circ} \mathrm{C}$. The minimum value of $\mathrm{L}^{*}$ was yield at $40^{\circ} \mathrm{C}$ i.e. maximum darkness and the maximum value of $\mathrm{L}^{*}$ was noticed at $110^{\circ} \mathrm{C}$ i.e. minimum darkness. It shows that at constant dyeing time about 60 minutes gradually increasing temperature has both positive and negative effects on lightness. The sample of $100^{\circ} \mathrm{C}, 80^{\circ} \mathrm{C}$, and $60^{\circ} \mathrm{C}$ were $1.60 \%, 2.18 \%$ and $3.60 \%$ respectively lighter than the sample of $40^{\circ} \mathrm{C}$ and the maximum lightness of the sample $110^{\circ} \mathrm{C}$ is $4.95 \%$ more light than the sample of $40^{\circ} \mathrm{C}$.

For dyeing at $100^{\circ} \mathrm{C}$ with varying dyeing time the samples order were found as 63.99> $62.56>62.51>62.32>61.76>60.42$ respectively for 110 $\min >70 \quad \min >80 \quad \min >60 \quad \min >50 \quad \min >100 \quad \min$. The minimum $L^{*}$ was yield for 100 minutes i.e. maximum darkness and for the sample 110 minutes i.e. the maximum lightness. It represents that at constant dyeing temperature $100^{\circ} \mathrm{C}$ gradually increasing dyeing time also have positive and negative effects on lightness $L^{*}$ value of dyed samples. The samples of $90,80,70,60$, and 50 minutes are $1.32 \%, 3.34 \%, 3.42 \%, 3.05 \%$ and $2.17 \%$ lighter than sample of 100 minutes. The minimum $L^{*}$ of 100 minutes sample was $5.58 \%$ darker than the sample of 110 minutes.

Regarding redness $\left(\mathrm{a}^{*}\right)$ for constant dyeing time at 60 minutes the order of the samples were recorded as $6.93>6.65>6.53>6.41>6.07$ for $80>60>110>40>100{ }^{\circ} \mathrm{C}$ respectively. The maximum redness was noticed for the sample of $80^{\circ} \mathrm{C}$ and the minimum for the sample of $100^{\circ} \mathrm{C}$. The samples of $110,80,60$ and $40^{\circ} \mathrm{C}$ were respectively $7.04 \%, 12.40 \%, 8.72 \%$ and $5.30 \%$ more red than the sample of $100^{\circ} \mathrm{C}$. For constant dyeing temperature at $100^{\circ} \mathrm{C}$ varying different temperature, the sample order found as $7.39>70.8>6.68>6.33>6.26>6.19>5.6$ respectively for $100>80>90>110>60>50>70$ minutes and maximum redness $\left(a^{*}\right)$ for the sample 100 minutes and minimum for 70 minutes. The samples of $110,100,90,80$, 60 and 50 minutes were respectively $11.53 \%, 24.22 \%$, $16.16 \%, 20.90 \%, 10.54 \%$ and $9.53 \%$ redder than the samples of 70 minutes. It clearly indicates that the gradually increase of time and temperature both have negative and positive effects on redness.

For yellowness $\left(b^{*}\right)$ at constant dyeing time at 60 minutes the order of samples were valued as $13.23>12.58>12.56>12.32>11.72$ respectively for $60>40>80>110>100^{\circ} \mathrm{C}$ and the maximum and minimum yellowness for the sample was yield at of $60^{\circ} \mathrm{C}$ and $100^{\circ} \mathrm{C}$ respectively. For the samples dyed at $110,80,60$ and $40^{\circ} \mathrm{C}$ were respectively $4.87 \%, 6.68 \%, 11.41 \%$ and $6.83 \%$ yellower than the sample of $100^{\circ} \mathrm{C}$. Similarly for the constant dyeing temperature at $100^{\circ} \mathrm{C}$ the samples represents order was found as $14.44>13.95>13.16>12.87>12.21>11.46>10.74$ for $100>80>110>90>50>60>70$ minutes respectively. The sample colored at $110,100,90,80,60,50$ minutes were $18.38 \%, 25.62 \%, 16.55 \%, 23.01 \%, 6.28 \%$ and $12.03 \%$ more yellow than the sample of 70 minutes.

In case of color saturation $\left(\mathrm{c}^{*}\right)$, the sample order obtain of constant dyeing about 60 minutes 14.81>14.31>14.12> $13.62>13.20$ respectively for $60>80>40>110>100^{\circ} \mathrm{C}$. Here highest saturation was measured for $60^{\circ} \mathrm{C}$ and lowest color saturation was looked at $100^{\circ} \mathrm{C}$. The samples of 110 , 80,60 , and $40^{\circ} \mathrm{C}$ were $3.08 \%, 7.75 \%, 10.87 \%$ and $6.51 \%$ more saturated respectively than the sample of $100^{\circ} \mathrm{C}$. Also the sample order for constant dyeing temperature at $100^{\circ} \mathrm{C}$ were found as $16.22>15.64>14.61>14.50>13.95>$ $13.69>12.21$ respectively for $100>80>110>90>60>50>70$ minutes where the maximum saturation level of samples was found for 100 minutes and minimum 70 minutes. The samples dyed at 110, 100, 90, 80, 60 and 50 minutes were $16.42 \%, 24.72 \%, 15.79 \%, 21.93 \% 12.73 \%$ and $10.81 \%$ more saturated respectively than the sample of 70 minutes. 
For hue $\left(\mathrm{h}^{\circ}\right)$ angle, at constant dyeing time 60 minutes the sample order were evaluated as $63.33>63.05>63.01>62.72>62.63$ respectively for $60>110>40>80>100^{\circ} \mathrm{C}$. The highest hue angle was calculated for $60^{\circ} \mathrm{C}$. Samples dyed at $110,80,60$ and 40 minutes were $0.67 \%, 0.14 \%, 1.10 \%$ and $0.60 \%$ higher correspondingly than $100^{\circ} \mathrm{C}$. For constant dyeing temperature at $100^{\circ} \mathrm{C}$ the samples order for hue angle $\left(\mathrm{h}^{\circ}\right)$ were looked as $64.31>$ $63.31>63.07>63.10>62.90>62.56>62.45$ for $110>60>80>50>100>90>70$ minutes respectively. The maximum value was observed for the samples of 110 minutes. The samples of $110,100,90,80,60$ and 50 minutes the hug angles were $2.9 \%, 0.71 \%, 0.17 \%, 0.98 \%, 1.35 \%$ and $1.03 \%$ higher than the sample of 70 minutes respectively.

The dynamic equilibrium state of dyeing process may be attained rapidly by raising the temperature and period for enhance the degree of fibre swelling and the rate of diffusion of dye molecules. But in case of 70 , and $90^{\circ} \mathrm{C}$ contradictory upshot looked probably due to chemical potential difference between dye-fiber molecule adsorption and desorption simultaneously taken place up to attain equilibrium [19].

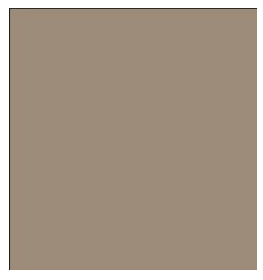

$110^{\circ} \mathrm{C}$

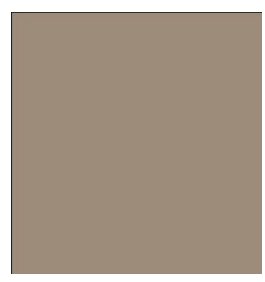

$100^{\circ} \mathrm{C}$

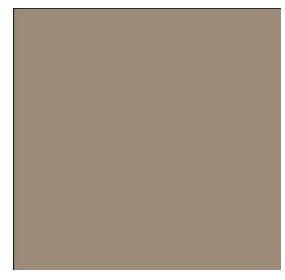

$80^{\circ} \mathrm{C}$

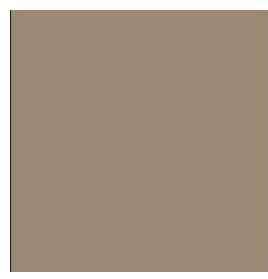

$60^{\circ} \mathrm{C}$

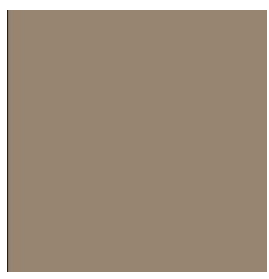

$40^{\circ} \mathrm{C}$

Figure 03: Images of different dyed samples dyeing temperature variation

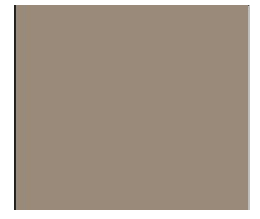

110 minutes

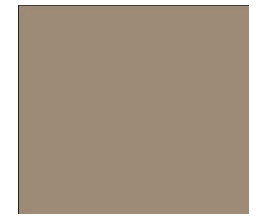

100 minutes

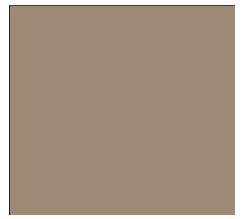

90 minutes

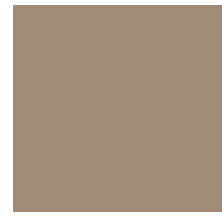

80 minutes

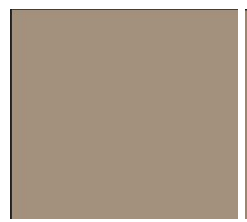

70 minutes

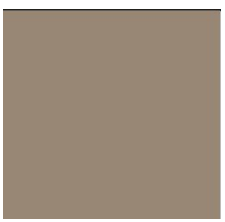

60 minutes

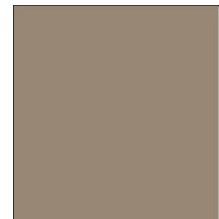

50 minutes

Figure 04: Images of different dyed samples dyeing time variation

Table 4. Table 4. Degree of color levelness

\begin{tabular}{|c|c|c|c|c|c|c|c|c|c|c|c|c|}
\hline \multicolumn{2}{|c|}{ Sample types } & \multicolumn{10}{|c|}{$\Delta \mathrm{E} \quad$ values of dyed samples } & \multirow{3}{*}{$\begin{array}{c}\text { Average } \\
(\Delta \mathrm{E})\end{array}$} \\
\hline \multirow{2}{*}{$\begin{array}{c}\text { Temp } \\
\left({ }^{\circ} \mathrm{C}\right)\end{array}$} & \multirow{2}{*}{$\begin{array}{c}\text { Time } \\
\text { (minutes) }\end{array}$} & $\mathrm{R} 1$ & $\mathrm{R} 2$ & R3 & R4 & R5 & R6 & R7 & $\mathrm{R} 8$ & R9 & $\mathrm{R} 10$ & \\
\hline & & \multicolumn{10}{|c|}{ Batch Readings } & \\
\hline $110^{\circ} \mathrm{C}$ & \multirow{5}{*}{$60 \mathrm{~min}$} & \multirow{12}{*}{ Standard } & 0.254 & 0.271 & 0.133 & 0.303 & 0.215 & 0.069 & 0.163 & 0.102 & 0.087 & 0.177 \\
\hline $100^{\circ} \mathrm{C}$ & & & 0.044 & 0.163 & 0.189 & 0.027 & 0.253 & 0.175 & 0.033 & 0.038 & 0.022 & 0.105 \\
\hline $80^{\circ} \mathrm{C}$ & & & 0.396 & 0.135 & 0.069 & 0.079 & 0.297 & 0.087 & 0.048 & 0.045 & 0.096 & 0.139 \\
\hline $60^{\circ} \mathrm{C}$ & & & 0.330 & 0.052 & 0.076 & 0.081 & 0.153 & 0.026 & 0.220 & 0.034 & 0.184 & 0.128 \\
\hline $40^{\circ} \mathrm{C}$ & & & 0.219 & 0.481 & 0.088 & 0.135 & 0.131 & 0.079 & 0.055 & 0.026 & 0.083 & 0.144 \\
\hline \multirow{7}{*}{$100^{\circ} \mathrm{C}$} & $110 \mathrm{~min}$ & & 0.0254 & 0.271 & 0.133 & 0.303 & 0.215 & 0.069 & 0.163 & 0.102 & 0.087 & 0.152 \\
\hline & $100 \mathrm{~min}$ & & 0.394 & 0.773 & 0.182 & 0.126 & 0.145 & 0.094 & 0.041 & 0.036 & 0.071 & 0.206 \\
\hline & $90 \mathrm{~min}$ & & 0.195 & 1.095 & 0.139 & 0.504 & 0.401 & 0.167 & 0.155 & 0.127 & 0.126 & 0.323 \\
\hline & $80 \mathrm{~min}$ & & 0.394 & 0.202 & 0.213 & 0.096 & 0.064 & 0.051 & 0.027 & 0.079 & 0.092 & 0.135 \\
\hline & $70 \mathrm{~min}$ & & 0.429 & 0.124 & 0.443 & 0.078 & 0.274 & 0.061 & 0.042 & 0.038 & 0.058 & 0.171 \\
\hline & $60 \mathrm{~min}$ & & 0.13 & 0.377 & 0.149 & 0.162 & 0.083 & 0.055 & 0.092 & 0.073 & 0.022 & 0.127 \\
\hline & $50 \mathrm{~min}$ & & 1.07 & 0.265 & 0.189 & 0.123 & 0.211 & 0.109 & 0.079 & 0.138 & 0.175 & 0.262 \\
\hline
\end{tabular}




\subsection{Degree of Color Levelness}

The table 04 represents the degree of color levelness of different dyed sample at various conditions. The dyeing temperature and time both has negative and positive effects on degree of color levelness [29]. The orders of sample for color levelness dyed at constant dyeing period about 60 minutes were noticed as $0.177>0.144>0.139>0.128>0.105$ respectively for $110>40>80>60>100{ }^{\circ} \mathrm{C}$. The lowest $\Delta \mathrm{E}$ value was recorded for sample $100^{\circ} \mathrm{C}$ i.e. the excellent levelness. The samples of $110,80,60$ and 40 were $40.67 \%, 24.46 \%$, $17.97 \%$ and $27.08 \%$ less level than the samples of $100^{\circ} \mathrm{C}$. Similarly for color levelness for constant dyeing temperature the orders of samples were determined as $0.323>0.262>0.206>0.171>0.152>0.135>0.127$

respectively for $90>50>100>70>110>80>60$ minutes where the excellent levelness obtain for 60 minutes samples i.e. lowest $\Delta \mathrm{E}$ value. Though there was color difference in $\Delta \mathrm{E}$, but all the samples exhibit excellent degree of color levelness. Though, there was difference in average color difference value but all samples showed excellent color levelness. The continuing upturn of dyeing time and temperature boosts the fiber swelling to promote easier penetration of dye into interior of the fiber homogeneously which conceivably leads positive impact on color levelness [19].

\subsection{Color Strength (K/S) Value, Reflectance and Brightness Index}

Figure 04 and 06 represents the color strength $(\mathrm{K} / \mathrm{S})$ value, reflectance and brightness index upshots different samples for dyeing time and temperature variation. For constant dyeing duration, at various temperature samples the order of $\mathrm{K} / \mathrm{S}$ values were recorded as $3.97>3.67>3.48>3.80>2.69$ for $100>110>80>60>40{ }^{\circ} \mathrm{C}$ respectively. Maximum $\mathrm{K} / \mathrm{S}$ values were revealed for the sample of $100^{\circ} \mathrm{C}$. The specimens of 110,80 and $60^{\circ} \mathrm{C}$ samples were $26.70 \%, 22.70 \%$ and $29.21 \%$ more strong respectively than the sample of $40^{\circ} \mathrm{C}$. The maximum color strength at $100^{\circ} \mathrm{C}$ was $32.24 \%$ higher than minimum.

Similarly for constant dyeing temperature at $100^{\circ} \mathrm{C}$ for altered dyeing duration the samples order were noticed as $3.51>3.49>3.47>3.15>3.12>2.52>2.43$

for $60>100>80>90>50>110>70$ minutes respectively. The maximum color strength at was appeared at 60 minutes. The samples of $110,90,80,60$ and 50 minutes dyeing period were calculated as $3.57 \%, 22.85 \%, 29.97 \%, 30.76 \%$ and $22.11 \%$ more strength respectively than that of 70 minutes. The minimum color strength was $30.37 \%$ higher than the lower color strength value. For successive increase in dyeing time and temperature the rate of diffusion of dye molecules in the bulk of dye bath increase the gradient of dye adsorption rate on fibre surface i.e. pseudo-second order rate constant remarkably which bolster the fashion of yielded $\mathrm{K} / \mathrm{S}$ values. Thermal degradation may be a probable reason of lower $\mathrm{K} / \mathrm{S}$ value at $110^{\circ} \mathrm{C}[19]$.

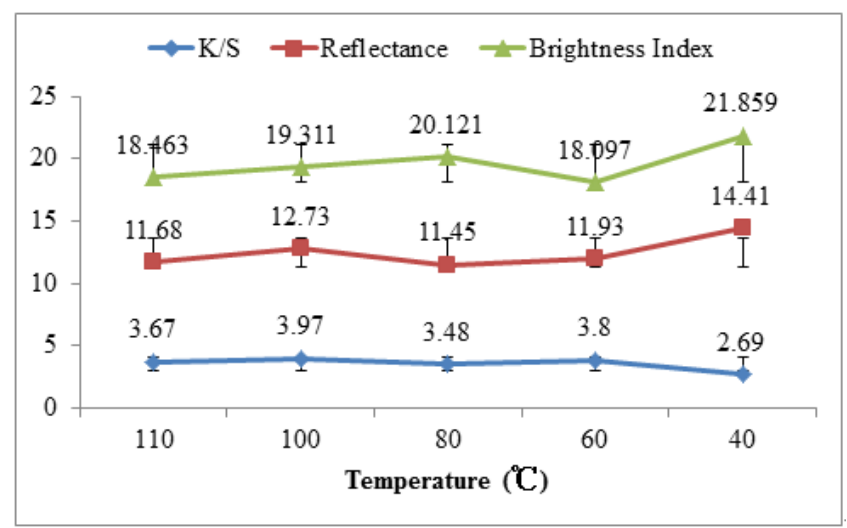

Figure 05. Color Strength (K/S) Value, Reflectance and Brightness Index

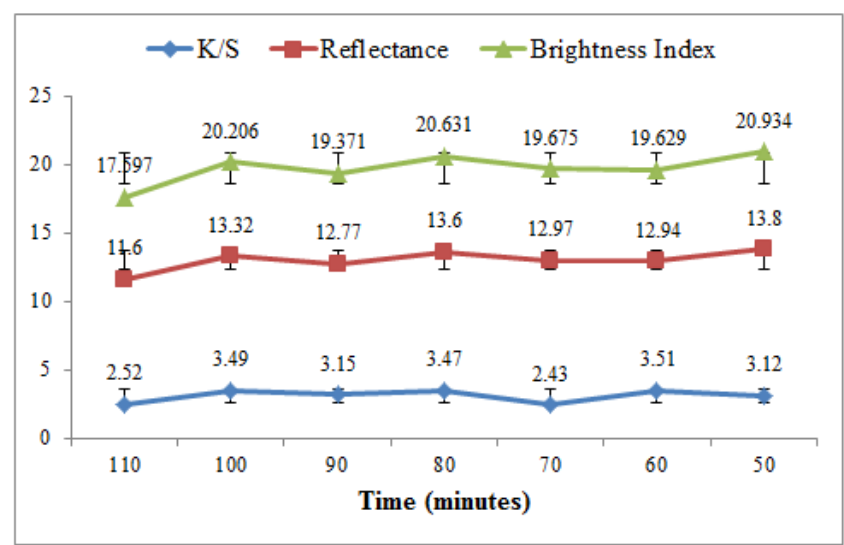

Figure: 06. Color Strength (K/S) Value, Reflectance and Brightness Index

In case of reflectance $\%$, the samples order was observed as $14.41>1273>11.93>11.68>11.45$ respectively for $40>100>60>110>80^{\circ} \mathrm{C}$ (figure 5 and 6 ) in case of the dyeing period 60 minutes. The minimum reflectance was obtained for the sample at $80^{\circ} \mathrm{C}$; more dark shade and it was $0.23 \%, 1.28 \%, 0.48 \%$ and $2.96 \%$ more than the sample of $110,100,60$ and $40^{\circ} \mathrm{C}$. The maximum reflectance was obtained for the sample at $40^{\circ} \mathrm{C}$ i.e. less color saturation. At $100^{\circ} \mathrm{C}$ for dyeing duration variation the samples order was measured as $13.80>13.60>13.32>12.97>12.94>1271>11.60$

respectively for the samples dyed for $50>80>100>70>60>90>110$ minutes. The minimum reflectance obtained for the samples 110 minutes which was $1.72 \%, 1.17 \%, 2 \%, 1.37 \%, 1.34$ and $2.2 \%$ more darker than 100, 90, 80, 70, 60 and 50 minutes separately.

The brightness index order of the samples were calculated as $21.895>20.121>19.311>18.463>18.097$ respectively for $40>80>100>110>60^{\circ} \mathrm{C}$ at constant dyeing duration 60 minutes. The maximum brightness was yielded for the sample of $60^{\circ} \mathrm{C}$ which was $1.98 \%, 6.28 \%$, $10.06 \%$ and $17.21 \%$ more bright than the samples of 110 , 
100,80 and $40^{\circ} \mathrm{C}$ respectively. The brightness order of samples for various dyeing duration at constant dyeing temperature $\quad 100{ }^{\circ} \mathrm{C}$ was noticed as $20.934>20.631>20.206>19.675>19.629>19.371>17.597$

for $50>80>100>70>60>90>110$ minutes respectively. The minimum brightness was obtained for the sample of 100 minutes which was $12.91 \%, 9.15 \%, 14.70 \%, 10.56 \%$, 10.35 and $15.94 \%$ lower bright than the samples of 100 , $90,80,70,60$ and 50 minutes respectively. The molecular structure of dye and fiber becomes open for proliferation of dyeing time and temperature which facilitates the dye adsorption rate and hence the lower brightness index i.e. darkest shade was obtained at $100^{\circ} \mathrm{C}[19]$.

\subsection{Color Fastness to Wash}

Table 05 indicates the colorfastness properties of different samples dyed in various conditions. All most overall result of colorfastness to wash was very good to excellent. The sample of $100^{\circ} \mathrm{C}$ and 60 minutes showed the optimum result little bit staining in wool. The sample dyed for 60 minutes at $100^{\circ} \mathrm{C}$ performed better against colorfastness to wash very good to excellent. It has a very good rating in cotton and polyester. Except samples at 40 and $110^{\circ} \mathrm{C}$ about dyeing 60 minutes all samples were exhibited excellent results in color change.

\subsection{Color Fastness to Rubbing and Light}

The performance of different conditional (time and temperature) dyed samples in case of rubbing and light fastness have showed in the table 06 . The overall results of colorfastness to rubbing were good to very good. The sample dyed at 100 and $80^{\circ} \mathrm{C}$ about 60 minutes were achieved the rating very good. Sample dyed at $100^{\circ} \mathrm{C}$ about 60 minutes showed very good rating in both dry and wet rubbing. The performance of the dyed samples against light fastness is fair to moderate but not satisfactory. The pigments of natural dye may be unstable in light because sunlight can damage the dye-fiber interaction.

Table 05. Colorfastness to wash

\begin{tabular}{|c|c|c|c|c|c|c|c|c|}
\hline \multicolumn{2}{|c|}{ Sample Type } & \multirow{2}{*}{$\begin{array}{c}\text { Change in } \\
\text { Color }\end{array}$} & \multicolumn{6}{|c|}{ Staining in color } \\
\hline Temp $\left({ }^{\circ} \mathrm{C}\right)$ & $\begin{array}{c}\text { Time } \\
\text { (minutes) }\end{array}$ & & Acetate & Cotton & Nylon & Polyester & Acrylic & Wool \\
\hline $110^{\circ} \mathrm{C}$ & \multirow{5}{*}{$60 \mathrm{~min}$} & 4 & $4-5$ & 4 & 4 & 4 & $4-5$ & 4 \\
\hline $100^{\circ} \mathrm{C}$ & & $4-5$ & $4-5$ & $4-5$ & $4-5$ & $4-5$ & $4-5$ & 4 \\
\hline $80^{\circ} \mathrm{C}$ & & $4-5$ & $4-5$ & 4 & 4 & $4-5$ & $4-5$ & 4 \\
\hline $60^{\circ} \mathrm{C}$ & & $4-5$ & $4-5$ & 4 & 4 & $4-5$ & $4-5$ & $4-5$ \\
\hline $40^{\circ} \mathrm{C}$ & & 4 & 4 & $4-5$ & 4 & $4-5$ & $4-5$ & 4 \\
\hline \multirow{7}{*}{$100^{\circ} \mathrm{C}$} & $110 \mathrm{~min}$ & $4-5$ & $3-4$ & $3-4$ & 4 & 4 & $3-4$ & $3-4$ \\
\hline & $100 \mathrm{~min}$ & $4-5$ & $4-5$ & 4 & $4-5$ & 4 & 4 & $4-5$ \\
\hline & $90 \mathrm{~min}$ & $4-5$ & 4 & 4 & $4-5$ & 4 & 4 & 4 \\
\hline & $80 \mathrm{~min}$ & $4-5$ & 4 & 4 & $4-5$ & $4-5$ & 4 & 4 \\
\hline & $70 \mathrm{~min}$ & $4-5$ & $4-5$ & 4 & 4 & 4 & 4 & 4 \\
\hline & $60 \mathrm{~min}$ & $4-5$ & $4-5$ & 4 & $4-5$ & 4 & $4-5$ & $4-5$ \\
\hline & $50 \mathrm{~min}$ & $4-5$ & $3-4$ & 4 & 4 & $3-4$ & 4 & 4 \\
\hline
\end{tabular}

Table 06. Color fastness to rubbing and light

\begin{tabular}{|c|c|c|c|c|}
\hline \multicolumn{2}{|c|}{ Sample Type } & \multicolumn{2}{|c|}{ Rubbing Fastness } & \multirow[b]{2}{*}{ Light Fastness } \\
\hline Temp $\left({ }^{\circ} \mathrm{C}\right)$ & Time (minutes) & Dry Rubbing & Wet Rubbing & \\
\hline $110^{\circ} \mathrm{C}$ & \multirow{5}{*}{60 minutes } & 4 & 3 & 2 \\
\hline $100^{\circ} \mathrm{C}$ & & $4-5$ & $3-4$ & $2-3$ \\
\hline $80^{\circ} \mathrm{C}$ & & $4-5$ & $3-4$ & $2-3$ \\
\hline $60^{\circ} \mathrm{C}$ & & 4 & $3-4$ & $2-3$ \\
\hline $40^{\circ} \mathrm{C}$ & & 4 & $2-3$ & 2 \\
\hline \multirow{7}{*}{$100^{\circ} \mathrm{C}$} & 110 minutes & 4 & 3 & 2 \\
\hline & 100 minutes & 4 & 3 & $2-3$ \\
\hline & 90 minutes & 4 & 3 & 2 \\
\hline & 80 minutes & 4 & $2-3$ & 3 \\
\hline & 70 minutes & 4 & $2-3$ & 2 \\
\hline & 60 minutes & 4 & $3-4$ & $2-3$ \\
\hline & 50 minutes & $3-4$ & $2-3$ & 2 \\
\hline
\end{tabular}




\subsection{Color Fastness to Water}

Table 07 illustrates the color fastness to water properties of different dyed sample. All most all sample showed the excellent result in case of color change and color staining without sample dyed at 110 and $40^{\circ} \mathrm{C}$ about 60 minutes due to low temperature or excess temperature in dyeing. At low temperature dye-fiber interaction causes less strength and may be in high temperature natural dyes are unstable.

Table 07. Colorfastness to Water

\begin{tabular}{|c|c|c|c|c|c|c|c|c|}
\hline \multicolumn{2}{|c|}{ Sample Type } & \multirow{2}{*}{$\begin{array}{c}\text { Change } \\
\text { in } \\
\text { Color }\end{array}$} & \multicolumn{6}{|c|}{ Staining in color } \\
\hline Temp $\left({ }^{\circ} \mathrm{C}\right)$ & $\begin{array}{c}\text { Time } \\
\text { (minutes) }\end{array}$ & & Acetate & Cotton & Nylon & Polyester & Acrylic & Wool \\
\hline $110^{\circ} \mathrm{C}$ & \multirow{5}{*}{$60 \mathrm{~min}$} & $4-5$ & $4-5$ & 4 & $4-5$ & 4 & $4-5$ & $4-5$ \\
\hline $100^{\circ} \mathrm{C}$ & & $4-5$ & $4-5$ & $4-5$ & $4-5$ & $4-5$ & $4-5$ & $4-5$ \\
\hline $80^{\circ} \mathrm{C}$ & & $4-5$ & $4-5$ & $4-5$ & $4-5$ & $4-5$ & $4-5$ & $4-5$ \\
\hline $60^{\circ} \mathrm{C}$ & & $4-5$ & $4-5$ & $4-5$ & $4-5$ & $4-5$ & $4-5$ & $4-5$ \\
\hline $40^{\circ} \mathrm{C}$ & & 4 & $4-5$ & 4 & $4-5$ & $4-5$ & $4-5$ & $4-5$ \\
\hline \multirow{7}{*}{$100^{\circ} \mathrm{C}$} & $110 \mathrm{~min}$ & $4-5$ & $4-5$ & $4-5$ & $4-5$ & $4-5$ & $4-5$ & $4-5$ \\
\hline & $100 \mathrm{~min}$ & $4-5$ & $4-5$ & $4-5$ & $4-5$ & $4-5$ & $4-5$ & $4-5$ \\
\hline & $90 \mathrm{~min}$ & $4-5$ & $4-5$ & $4-5$ & $4-5$ & $4-5$ & $4-5$ & $4-5$ \\
\hline & $80 \mathrm{~min}$ & $4-5$ & $4-5$ & $4-5$ & $4-5$ & $4-5$ & $4-5$ & $4-5$ \\
\hline & $70 \mathrm{~min}$ & $4-5$ & $4-5$ & $4-5$ & $4-5$ & $4-5$ & $4-5$ & $4-5$ \\
\hline & $60 \mathrm{~min}$ & $4-5$ & $4-5$ & $4-5$ & $4-5$ & $4-5$ & $4-5$ & $4-5$ \\
\hline & $50 \mathrm{~min}$ & $4-5$ & $4-5$ & $4-5$ & $4-5$ & $4-5$ & $4-5$ & $4-5$ \\
\hline
\end{tabular}

\subsection{Color Fastness to Perspiration}

Table 08 showed the result of colorfastness to perspiration of different dyed samples. Overall result of colorfastness to perspiration both acidic and alkaline was very good to excellent. Except $110^{\circ} \mathrm{C}$ color change of dyed samples were very good to excellent but staining in color good to very good. It causes worst result at low dyeing temperature and low dyeing time 50 minutes $40^{\circ} \mathrm{C}$.

With increasing the dyeing temperature and time it improves the fastness properties may be due to their better fixation as example 80 and $100^{\circ} \mathrm{C}$ dyed sample about 60 minutes also $60,70,80,90$ and 100 minutes samples at $100^{\circ} \mathrm{C}$. Higher dyeing time and temperature may swell the fiber more as dye uptake and fixation more but excess time and temperature may cases the damage of natural dye due to their instability and also damaged by excessive alkaline or acidic condition.

Table 08. Colorfastness to Perspiration

\begin{tabular}{|c|c|c|c|c|c|c|c|c|}
\hline \multicolumn{2}{|c|}{ Sample Type } & \multirow{2}{*}{$\begin{array}{c}\text { Change in } \\
\text { Color }\end{array}$} & \multicolumn{6}{|c|}{ Staining in color } \\
\hline Temp $\left({ }^{\circ} \mathrm{C}\right)$ & Time (minutes) & & Acetate & Cotton & Nylon & Polyester & Acrylic & Wool \\
\hline $110^{\circ} \mathrm{C}$ & \multirow{5}{*}{$60 \mathrm{~min}$} & 4 & $4-5$ & 4 & $3-4$ & $3-4$ & $3-4$ & 4 \\
\hline $100^{\circ} \mathrm{C}$ & & $4-5$ & $4-5$ & 4 & 4 & $4-5$ & 4 & 4 \\
\hline $80^{\circ} \mathrm{C}$ & & $4-5$ & 4 & 4 & 4 & $4-5$ & 4 & 4 \\
\hline $60^{\circ} \mathrm{C}$ & & $4-5$ & $4-5$ & 4 & 4 & 4 & 4 & $4-5$ \\
\hline $40^{\circ} \mathrm{C}$ & & $4-5$ & 4 & $3-4$ & $3-4$ & 4 & $3-4$ & 4 \\
\hline \multirow{7}{*}{$100^{\circ} \mathrm{C}$} & $110 \mathrm{~min}$ & $4-5$ & $3-4$ & $3-4$ & 4 & 4 & 4 & $3-4$ \\
\hline & $100 \mathrm{~min}$ & $4-5$ & $4-5$ & 4 & $4-5$ & 4 & 4 & $4-5$ \\
\hline & $90 \mathrm{~min}$ & $4-5$ & 4 & 4 & $4-5$ & 4 & 4 & 4 \\
\hline & $80 \mathrm{~min}$ & $4-5$ & 4 & 4 & $4-5$ & $4-5$ & 4 & 4 \\
\hline & $70 \mathrm{~min}$ & $4-5$ & $4-5$ & 4 & 4 & 4 & 4 & 4 \\
\hline & $60 \mathrm{~min}$ & $4-5$ & 4 & 4 & $4-5$ & 4 & $4-5$ & $4-5$ \\
\hline & $50 \mathrm{~min}$ & $4-5$ & $3-4$ & 4 & 4 & $3-4$ & 4 & 4 \\
\hline
\end{tabular}


With increment of dyeing time and temperature, specimens showed a slight improvement in overall color fastness properties. For raising dying time and temperature it is evident that, the stronger dye-fiber bond due to higher rate of diffusion of dye molecules, the easier is the transfer of the excitation energy from the dye molecule to the fiber macromolecular chain. Moreover, higher dyeing time and temperature leads swelling of cellulose fibers. Thus, the dye fiber linkage assists as a bridge for conveying the excitation energy between the two components of the dye fiber ambient coordination. So, color fastness upturns at higher time and temperature for stronger dye-fiber interaction. But color durability properties downturns after raising temperature than $100^{\circ} \mathrm{C}$ for thermal instability of natural dye molecule $[19,30]$.

\section{Conclusions}

The extracted dye from mango seed kernel agronomical bio-waste was successfully employed for dyeing of cellulosic fiber. Cotton knitted single jersey fabric which investigated in this study deliver light medium to dark shade. This study revealed the dyeing time and temperature both have significant effect on shade and tones. The optimized colorimetric and serviceability were found for the specimens which were colored at $100^{\circ} \mathrm{C}$ for 60 minutes. Light fastness was not satisfactory. For prolong dyeing time and temperatures have adverse effect on all colorimetric properties which corresponds to degradation of dye molecules. From all color fastness properties it can be clinched that mango seed kernel dye can be applied from the fabric where the importance of light fastness is negligible. Further investigation for improvement of light fastness, serviceability and colorimetric properties mordanting and proper extraction of natural dye can be carried out.

\section{REFERENCES}

[1] Kant, R. (2012(. Textile dyeing industry an environmental hazard. Natural science, 4)1(, 22-26.

[2] Chakraborty, J. N. (Ed.). (2015(. Fundamentals and practices in colouration of textiles. CRC Press.

[3] Kapdan, I. K., Kargia, F., McMullan, G., \& Marchant, R. (2000(. Effect of environmental onditions on biological decolorization of textile dyestuff by C. versicolor. Enzyme and Microbial Technology, 26)5-6(, 381-387.

[4] Rovira, J., Nadal, M., Schuhmacher, M., \& Domingo, J. L. (2015(. Human exposure to trace elements through the skin by direct contact with clothing: Risk assessment. Environmental research, 140, 308-316.

[5] Repon, M. R., Islam, M. T., \& Al Mamun, M. A. (2017).
Ecological risk assessment and health safety speculation during color fastness properties enhancement of natural dyed cotton through metallic mordants. Fashion and Textiles, 4(1), 24.

[6] Chavan, R. B. (2011(. Environmentally friendly dyes. In Handbook of textile and industrial dyeing (pp. 515-.(561

[7] Samanta, A. K., \& Agarwal, P. (2009(. Application of natural dyes on textiles.

[8] Chakraborty, J. N. (Ed.). (2015(. Fundamentals and practices in colouration of textiles. CRC Press.

[9] Abdalla, A. E., Darwish, S. M., Ayad, E. H., \& El-Hamahmy, R. M. (2007(. Egyptian mango by-product 1. Compositional quality of mango seed kernel. Food chemistry, 103)4(, 1134-1140.

[10] Ganeshan, G., Shadangi, K. P., \& Mohanty, K. (2016(. Thermo-chemical conversion of mango seed kernel and shell to value added products. Journal of Analytical and Applied Pyrolysis, 121, 403-408.

[11] Torres-León, C., Rojas, R., Serna-Cock, L., Belmares-Cerda, R., \& Aguilar, C. N. (2017(. Extraction of antioxidants from mango seed kernel: Optimization assisted by microwave. Food and Bioproducts Processing, 105, 188-196.

[12] Kittiphoom, S. (2012(. Utilization of mango seed.

[13] Kumar, K. V., \& Kumaran, A. (2005(. Removal of methylene blue by mango seed kernel powder. Biochemical Engineering Journal, 27)1(, 83-93.

[14] Khattri, S. D., \& Singh, M. K. (2000(. Colour removal from synthetic dye wastewater using a bioadsorbent. Water, Air, and Soil Pollution, 120)3-4(, 283-294.

[15] Elizalde-González, M. P., \& Hernandez-Montoya, V. (2007. Characterization of mango pit as raw material in the preparation of activated carbon for wastewater treatment. Biochemical Engineering Journal, 36)3(, 230-238.

[16] Shah, K. A., Patel, M. B., Patel, R. J., \& Parmar, P. K. (2010(. Mangifera indica (mango). Pharmacognosy reviews, 4)7(, 42.

[17] Shukla, D., \& Vankar, P. S. (2017(. Innovative dye extraction methods. Natural Dyes for Textiles: Sources, Chemistry and Applications, 191.

[18] Repon, M. R., Al Mamun, M. A., \& Islam, M. T. (2016). Optimization of dyeing time of eco-friendly cotton coloration using banana (Musa sapientum) floral stem sap. Chemical and Materials Engineering, 4(2), 26-31.

[19] Repon, M. R., Al Mamun, M. A., \& Islam, M. T. (2016). Eco-friendly cotton coloration using banana (Musa sapientum) waste: optimization of dyeing temperature. Universal Journal of Engineering Science, 4(1), 14-20.

[20] Millward, S. (2009(. Color difference equations and their assessment. Test Target J, 9, 19-26.

[21] Paper and board: Measurement of diffused blue reflectance factor (ISO-brightness) ISO 2469 \& 2470, 2nd (International Prganization for Standaradization Switzerland), 1977,1. 
[22] MacDougall, D. B. (2010(. Colour measurement of food: principles and practice. In Colour Measurement (pp. 312-342(.

[23] Borch, J. E. N. S. (2002(. Optical and appearance properties. Handbook of Physical Testing of Paper, 2, 90-.149

[24] ISO, E. 105-C06: 2010, Textiles, Tests for colour fastness, Part C06: Colour fastness to domestic and commercial laundering. Tekstiil. Värvipüsivuse katsetamine. Osa C, 6.

[25] AATCC. 2013. AATCC Test Method 8-2013 Colorfastness to Rubbing.

[26] AATCC. 1996. AATCC Test Method 125-2013 Colorfastness to light.
[27] AATCC. 2008. AATCC Test Method 107-2013 Colorfastness to Water.

[28] AATCC. 2006. AATCC Test Method 15-2013 Colorfastness to Perspiration.

[29] Repon, M. R., Islam, M. T., \& Al Mamun, M. A. (2016). Promising Effect of Metallic Mordants on Colorimetric Physiognomy of Dyed Cotton Fabric Employing Banana (Musa Sapientum) Agricultural Waste. Chemicals and Materials Engineering 4(3),39 -45.

[30] Repon, M. R., Islam, M. T., Al Mamun, M. A., \& Rashid, M.A. (2018). Comparative study on natural and reactive dye for cotton coloration. Journal of Applied Research and Technology, 16(3): 160-169. 